\title{
MIXED COMPETITION AND WELFARE UNDER VARIOUS NONPROFIT OBJECTIVES
}

\author{
MIXED COMPETITION \\ UNDER VARIOUS COST \\ CONFIGURATIONS
}

Petra Brhlíková
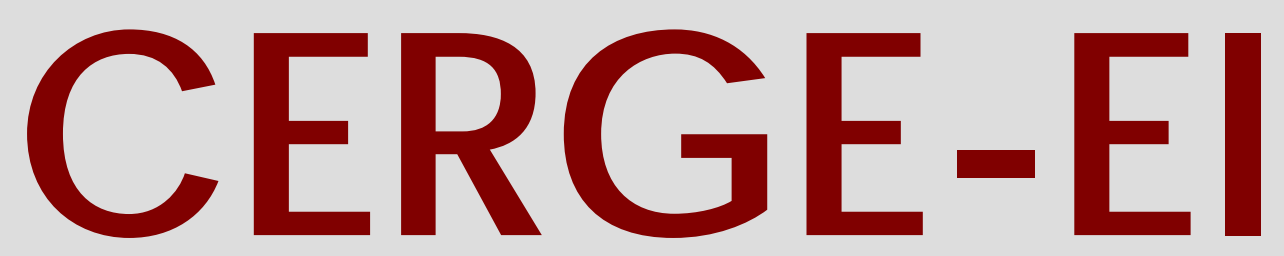

Charles University CenterforEconomic Research and Graduate Education Academy of Sciences of the Czech Republic Ec onomic Institute 


\title{
Working Paper Series (ISSN 1211-3298)
}

\section{Mixed Competition and Welfare under Various Nonprofit Objectives}

\author{
Mixed Competition \\ under Various Cost Configurations
}

\author{
Petra Brhlíková
}

CERGE-EI

Prague, October 2006 
ISBN 80-7343-106-8 (Univerzita Karlova. Centrum pro ekonomický výzkum a doktorské studium) ISBN 80-7344-095-4 (Akademie věd České republiky. Národohospodářský ústav) 


\title{
Mixed Competition and Welfare under Various Nonprofit Objectives Mixed Competition under Various Cost Configurations*
}

\author{
Petra Brhlíková ${ }^{\dagger}$ \\ CERGE-EI ${ }^{\ddagger}$
}

October 2006

\begin{abstract}
I study the competition between one nonprofit and one for-profit firm under various objective functions of the nonprofit firm. The two firms optimize their objectives with respect to quality and price of their products. The nonprofit firm serves one-half of the market under pure quality maximization, while it serves about twothirds under two other objective functions that in addition to quality, include market share. In contrast, the market share and profit of the for-profit firm decrease, and consumer and total surplus increase.

For the case of quality maximization pursued by the nonprofit firm, I derive equilibria for several cost configurations. Qualities and prices offered depend on the steepness of the cost function as well as on the proportion between fixed and variable costs.
\end{abstract}

\begin{abstract}
Abstrakt
Analyzujem sút' až medzi jednou ziskovou a jednou neziskovou firmou za predpokladu rôznych účelových funkcií neziskovej firmy. Firmy optimalizujú svoje ciele vzhl'adom na kvalitu a cenu svojich produktov. Nezisková firma poskytuje svoj produkt polovici spotrebitel'ov pri maximalizácii kvality, kým jej podiel na trhu je približne dve tretiny pri d'alších dvoch účelových funkciách, ktoré okrem kvality zahŕňajú aj podiel na trhu. Podiel na trhu a zisk ziskovej firmy naopak klesajú, spotrebitel'ský a celkový prebytok rastú. Pre prípad maximalizácie kvality neziskovou firmou odvádzam rovnovážne kvality a ceny pre niekol'ko špecifikácií nákladovej funkcie. Ponúkané kvality a ceny produktov závisia od sklonu nákladovej funkcie ako aj podiele fixných a variabilných nákladov na celkových nákladoch.
\end{abstract}

Keywords: Nonprofit, For-profit, Competition JEL classification: L21, L31, L11

*I thank Marc Bilodeau, Andreas Ortmann, and Richard Steinberg for helpful comments.

${ }^{\dagger}$ Email: Petra.Brhlikova@cerge-ei.cz

${ }^{\ddagger}$ A joint workplace of the Center for Economic Research and Graduate Education, Charles University, Prague, and the Economics Institute of the Academy of Sciences of the Czech Republic. Address: CERGE-EI, P.O. Box 882, Politických vězňů 7, Prague 1, 111 21, Czech Republic 


\section{Introduction}

Nonprofit and for-profit firms co-exist and compete in areas such as health and social care, education, and art production (Rose-Ackerman 1996). Market shares of nonprofit and for-profit firms vary across industries and within industries across time (RoseAckerman 1996; Hansmann 1994). The variation might result from different objectives pursued by nonprofit firms or different groups of consumers they aim to serve and also from cost structures that differ among industries.

In this paper, I focus on a mixed duopoly with vertical product differentiation. The two firms, one nonprofit and one for-profit, have different objectives, face different constraints, and compete over qualities and prices. The effects of various nonprofit objectives on equilibrium qualities, prices, and market shares as well as on welfare are analyzed. The effects of several cost specifications for one particular nonprofit objective function, quality maximization, on equilibrium outcome is also studied.

Mixed competition between nonprofit and for-profit firms has been analyzed in several studies. In light of the often alleged inefficiency of nonprofits (attributed to the absence of owners), it is at first sight surprising that nonprofits can successfully compete with strictly profit-maximizing firms. Among the obvious reasons that explain nonprofits' competitiveness are tax and regulatory breaks that the state bestows on nonprofits to support their socially beneficial activities (Facchina, Showell, and Stone 1993).

With respect to the alleged inability of nonprofits to compete with for-profits, Friesner and Rosenman (2001) show that nonprofits are able to compete with for-profit firms even without barriers to entry, regulatory and tax breaks, and other subsidies. Under certain conditions a nonprofit's ability to compete can be improved by increasing the nonpecuniary benefits in the form of quality or service, i.e. prestige. Similarly, the results in Brhlíková (2004) suggest that a nonprofit can successfully compete with a forprofit. Moreover, the nonprofit acts as a natural leader in the market. This is due to the zero-profit constraint faced by the nonprofit, which represents the non-distribution 
constraint, implying that the nonprofit behaves more aggressively than the for-profit.

Liu and Weinberg (2004) show that competition has a positive impact on nonprofit production since it diminishes inefficiencies in the firm. Liu and Weinberg also show that the competition with a nonprofit with regulatory advantages has only a marginal effect on the for-profit. The different objectives are instead the main force for the competitive outcome. This result coincides with findings presented in Brhlíková (2004) and Harrison and Lybecker (2005) that suggest that the competition with a nonprofit might be advantageous for the for-profit in comparison to the competition with another for-profit. If the nonprofit delivers a significantly different product (e.g. under quality maximization) than the for-profit, then sufficient maneuvering space for the for-profit to increase its profits is left. That maneuvering space is not available when both firms maximize their profits. The nonprofit could, however, sacrifice high quality in order to increase its market share. Product differentiation then narrows and the tougher competition decreases profit of the for-profit.

The findings summarized above suggest that the equilibrium outcome depends on objectives pursued by nonprofits and for-profits. The objectives of nonprofits, unfortunately, cannot be defined as clearly and simply as the objectives of for-profits. In general, nonprofits aim to provide publicly beneficial services but their specific goals vary across industries as well as within particular industries. For instance, Newhouse (1970), analyzing nonprofits in health care, suggests a combination of quality and quantity as a nonprofit objective. In addition to quality and quantity, Hansmann (1981) considers budget maximization to be included in the objective function of art performing firms. Steinberg (1986) estimates a nonprofit objective function within a family of functions with service maximization (maximization of net revenue available for service provision) and budget maximization as limiting cases. The empirical test suggests that welfare, education, and arts firms are service maximizers while health firms are budget maximizers.

Among studies that focus on competition between nonprofits and for-profits, Liu and 
Weinberg (2004) look at output maximization pursued by the nonprofit. Friesner and Rosenman (2001) assume that the nonprofit maximizes a convex combination of quality and quantity of services and nonpecuniary benefits. These nonpecuniary benefits include prestige that is increasing in quality of services provided and perquisites. Harrison and Lybecker (2005) analyze the effect of the profit motive on competitive behavior of nonprofit hospitals. Hospitals are assumed to maximize a combination of profit and a nonprofit objective such as quantity, quality, or the provision of care to the needy.

Table 1 summarizes nonprofit objectives assumed in the literature.

\begin{tabular}{|c|c|}
\hline NP objective & \\
\hline quality & Newhouse (1970), Hansmann (1981), \\
\hline & Friesner and Rosenman (2001), \\
\hline & Harrison and Lybecker (2005) \\
\hline quantity & Newhouse (1970), Hansmann (1981), \\
\hline & Friesner and Rosenman (2001), \\
\hline & Liu and Weinberg (2004), \\
\hline & Harrison and Lybecker (2005) \\
\hline care to needy & Harrison and Lybecker (2005) \\
\hline budget & Hansmann (1981), Steinberg (1986) \\
\hline profit & Steinberg $(1986)^{1}$, \\
\hline & Harrison and Lybecker (2005) \\
\hline net income per staff member & Pauly and Redisch (1973) \\
\hline nonpecuniary benefits & $\begin{array}{l}\text { Friesner and Rosenman (2001), } \\
\text { Glaeser and Shleifer (2001) }\end{array}$ \\
\hline
\end{tabular}

Table 1: Objectives of nonprofits as found in the literature

In the present paper, similarly to Friesner and Rosenman (2001) and Brhlíková (2004), I analyze competition between one nonprofit and one for-profit over qualities and prices. In the first part, I compare equilibria under three different objective functions of the nonprofit. The assumed nonprofit objectives are quality maximization, here summarized in Section 2 (Brhlíková 2004); maximization of nonprofit quality and market share (subsection 3.1); and maximization of quality and market share of both firms (subsection 3.2). The goal is to explore the ability of nonprofits to compete with for-profits and to

\footnotetext{
${ }^{1}$ Steinberg assumes that all available profits are used for service provision, i.e. to enhance quality, increase quantity, or both.
} 
compare distinctive features of equilibria resulting from different objectives. Welfare consequences of the three nonprofit objectives are also discussed.

In the second part of the paper, I study competitive equilibria for one of the nonprofit objectives (quality maximization) and for various cost specifications (Section 4). I depart from Brhlíková (2004) that assumes quality maximization as the nonprofit objective and fixed costs of producing a certain quality (quadratic in quality). Incorporating variable production costs make the model better suited for the analysis of the coexistence of nonprofits and for-profits in health care, where the variable cost component is nonnegligible. In addition, the differences in cost structure are probably the key driver of the variation in market shares of nonprofits and for-profits across industries where they coexist. Specifically, I consider several degrees of steepness of cost functions and the effects of variable costs on equilibrium qualities, prices, and market shares of the two competing firms. The fifth section concludes.

\section{Model}

In this section, I follow the model of mixed duopoly competition from Brhlíková (2004). One nonprofit and one for-profit that compete within an industry are considered. The forprofit is assumed to maximize its profit while the nonprofit maximizes its quality ${ }^{2}$ and faces a zero-profit constraint. The zero-profit constraint represents the non-distribution constraint imposed on nonprofits, which requires all profits to be invested in the provision of services. In Brhlíková (2004), it is assumed that all advantages bestowed on nonprofits such as tax and regulatory breaks as well as availability of donations are aggregated in a subsidy. This subsidy lowers the part of production costs that has to be covered by consumers' payments. In the present paper, I omit this assumption since the effect of subsidies seems to be of comparatively little importance. Qualities and prices depend

\footnotetext{
${ }^{2}$ The model assumes the simplest possible objective, quality maximization, of the nonprofit. In the following sections, I analyze alternative nonprofit's objectives.
} 
for the most part on the specification of the nonprofit objective (Liu and Weinberg 2004; Harrison and Lybecker 2005).

Demand is derived from consumers' preferences. Heterogeneous consumers maximize an additive utility function, $U_{i}\left(\theta_{i} q, x\right)=\theta_{i} q+x$, where $\theta$ represents consumers' sensitivity to quality and is uniformly distributed over $\langle 0,1\rangle ; q$ is the quality of public good; and $x$ is the amount of a private good that is purchased outside the industry of interest here. Individuals' demand is constrained by budget, $p_{j}+x p_{x}=w \cdot p_{j}$ is the price of the public good bought from the nonprofit $(j=n)$; for-profit $(j=f)$; or not at all $\left(j=z\right.$, zero price). The price of the private good, $p_{x}$, is normalized to one.

In the market for the public good, consumers choose among three quality-price bundles: nonprofit $\left(q_{n}, p_{n}\right)$; for-profit $\left(q_{f}, p_{f}\right)$; and non-buying option $\left(q_{z}, p_{z}\right)$. Since the nonprofit produces higher quality than the for-profit ${ }^{3}$, consumers with the highest sensitivity to quality prefer the nonprofit product. Specifically, all consumers with sensitivity parameter $\theta \in\left\langle\frac{p_{n}-p_{f}}{q_{n}-q_{f}}, 1\right\rangle$ prefer the nonprofit producer; consumers with $\theta \in\left\langle\frac{p_{f}}{q_{f}}, \frac{p_{n}-p_{f}}{q_{n}-q_{f}}\right\rangle$ prefer the for-profit product; and consumers with $\theta \in\left\langle 0, \frac{p_{f}}{q_{f}}\right\rangle$ prefer the non-buying option. The market shares of the two firms are $t_{n}=1-\frac{p_{n}-p_{f}}{q_{n}-q_{f}}$ and $t_{f}=\frac{p_{n}-p_{f}}{q_{n}-q_{f}}-\frac{p_{f}}{q_{f}}$.

The two firms choose the quality and price of the product in two stages regardless of the nonprofit maximand. In the first stage, they simultaneously choose qualities, $q_{n}$ and $q_{f}$

$$
\begin{array}{ll}
\mathrm{NP}: & \max q_{n} \\
\mathrm{FP}: & \max t_{f} p_{f}-c\left(q_{f}\right) .{ }^{4}
\end{array}
$$

\footnotetext{
${ }^{3}$ See the discussion in Brhlíková (2004).

${ }^{4}$ Production costs are assumed to be fixed costs of producing a certain quality. Costs are increasing and convex in quality. Specifically, I assume costs to be quadratic in quality, $c(q)=q^{2}$. In Section 4 , I also
} 
In the second stage, firms choose optimal prices, $p_{n}$ and $p_{f}$

$$
\begin{aligned}
& \text { NP : } \quad \text { choose } p_{n} \text { s.t. } t_{n} p_{n}=c\left(q_{n}\right) \\
& \text { FP : } \quad \max _{p_{f}} t_{f} p_{f}-c\left(q_{f}\right)
\end{aligned}
$$

Solving the problem backward, first-order conditions in the second stage are as follows:

$$
\begin{array}{r}
\left(1-\frac{p_{n}-p_{f}}{q_{n}-q_{f}}\right) p_{n}-q_{n}^{2}=0 \\
p_{f}-\frac{p_{n} q_{f}}{2 q_{n}}=0
\end{array}
$$

These two conditions determine optimal prices $p_{n}^{*}\left(q_{n}, q_{f}\right)$ and $p_{f}^{*}\left(q_{n}, q_{f}\right)$. The optimization problems in the first stage, together with the optimal prices, then lead to the following first-order conditions:

$$
\begin{aligned}
q_{n}-\frac{1+2 q_{f}+\sqrt{\left(1+2 q_{f}\right)^{2}-16 q_{f}}}{8} & =0 \\
-2 q_{f}+\frac{q_{n} q_{f}\left(q_{n}-q_{f}\right)}{2\left(2 q_{n}-q_{f}\right)^{3}}+\frac{q_{n}\left(q_{n}-2 q_{f}\right)}{4\left(2 q_{n}-q_{f}\right)^{2}} & =0
\end{aligned}
$$

In equilibrium, the nonprofit produces higher quality at a higher price than the forprofit and serves half of the market. The for-profit serves slightly above one quarter of the market and earns a strictly positive profit ${ }^{5}$.

work with a scaled quadratic, shifted cubic, and a linear combination of variable and fixed cost functions. As mentioned above, I abstract from subsidies given to nonprofits here. Results for quality maximization presented here correspond to results in Brhlíková (2004) for $s=0$.

${ }^{5}$ The closed form solution does not seem to exist for this problem. The numerical solution is presented in Table 2 (see the subsection 3.2). 


\section{Alternative Objectives of the Nonprofit}

In the previous section, the nonprofit maximizes the quality of an excludable public good. Many nonprofits, however, care also about their market share. The reason might be economies of scale or an attempt to increase consumers' exposure to the quality they provide. High quality arts and religious education are examples of fields where such goals are common.

In this section, I focus on objective functions of the nonprofit that include market share of the general form of $q_{n} t_{n}+k q_{f} t_{f}$ for $k \in\langle 0,1\rangle$. Specifically, I look at the two limiting cases, $k \in\{0,1\}$. For $k=0$, the nonprofit cares about its own quality and market share, i.e. the nonprofit thinks that people should consume a high quality good, more precisely the high-quality nonprofit good, and therefore aims at serving as many consumers as possible with the highest possible quality. For $k=1$, the nonprofit cares about the quality and market share of the for-profit in addition to its own quality and market share. The nonprofit has a paternalistic objective and thinks that the consumption of the particular public good is beneficial in general. The nonprofit, however, cannot serve all the market with a high quality. Therefore, it wants the for-profit to serve also as many consumers as possible with a relatively high quality.

\subsection{The Nonprofit Maximizes $q_{n} t_{n}$}

The nonprofit is assumed to maximize its product quality and market share. Under the assumption of fixed production costs, it is always better for the nonprofit to have larger market share. The costs, however, increase with quality and there might not be a sufficient number of consumers, heterogeneous with respect to their taste for quality, that want to purchase the high nonprofit quality. Thus, there is a trade off between higher quality for smaller market share and lower quality for larger market share. Production decisions of the two firms are again made in two stages. First, the two firms simultane- 
ously choose optimal qualities

$$
\begin{array}{ll}
\text { NP }: & \max _{q_{n}} q_{n} t_{n} \\
\text { FP }: & \max _{q_{f}} t_{f} p_{f}-q_{f}^{2}
\end{array}
$$

Then, given equilibrium qualities they simultaneously choose prices

$$
\begin{aligned}
& \text { NP : } \quad \max _{p_{n}} q_{n} t_{n} \text { s.t. } t_{n} p_{n}=q_{n}^{2} \\
& \text { FP : } \quad \max _{p_{f}} t_{f} p_{f}-q_{f}^{2}
\end{aligned}
$$

where $t_{n}$ and $t_{f}$ are market shares as derived above.

Despite the difference in the nonprofit objective, the second stage leads to the same decision with respect to prices as in the previous section (pure quality maximization by the nonprofit). This is due to the non-distribution constraint being binding and indeed determining the nonprofit pricing strategy irrespective of the nonprofit objective. The second stage thus leads to the same first-order conditions as in Section 2 and optimal prices are determined in the same way. The difference is only in the first stage when the nonprofit maximizes the product of its quality and market share. Since the nonprofit cares also about market share, it is willing to sacrifice a high quality in favor of its market share. ${ }^{6}$ The equilibrium qualities, prices, and market shares under quality and qualitymarket share maximization are summarized in Table 2 (see subsection 3.2). ${ }^{7}$

The nonprofit, indeed, decreases its quality when compared to the pure quality maximization case. Now, it is able to lower its price and attract additional consumers that were served by the for-profit previously. The nonprofit now serves two thirds of the market (compared to one-half.)

\footnotetext{
${ }^{6}$ First-order conditions for the first stage are now more complicated than in the case of pure quality maximization. For computational details see Appendix 7.1 on page ....

${ }^{7}$ As in Brhlíková (2004), a closed form solution does not seem to exist for this problem. The table summarizes numerical solutions.
} 
The for-profit also has to cover its production costs and since a part of 'its' consumers now prefers the nonprofit product, it wants to attract additional consumers from the low end of the taste distribution, i.e. the consumers that previously preferred the non-buying option. The for-profit, therefore, also decreases its quality and price. The for-profit's market share is less than one-fifth (compared to one-quarter.) Its profit decreases since the for-profit serves consumers with a smaller willingness to pay.

This shift toward consumers that were not served under quality maximization, has a positive consequence for the total market share served. In addition, as mentioned, the profit of the for-profit decreases, and therefore, consumer surplus increases when compared to the case of pure quality maximization pursued by the nonprofit (see Table 3, subsection 3.3). The total surplus also increases.

\subsection{The Nonprofit Maximizes $q_{n} t_{n}+q_{f} t_{f}$}

In this subsection, the nonprofit is concerned about the quality and market share of the for-profit as well. The nonprofit now operates as public motive maximizer or ideologist, who thinks that the consumption of high quality products is good for consumers and cares about customers of the for-profit in addition to its own customers. The nonprofit thus wants to serve as many consumers as possible with the maximal feasible quality (just because it is beneficial for consumers) and also wants the for-profit to do the same.

The quality-price setting is again done in two stages. First, the two firms simultaneously choose optimal qualities

$$
\begin{aligned}
& \mathrm{NP}: \max _{q_{n}} q_{n} t_{n}+q_{f} t_{f} \\
& \mathrm{FP}: \max _{q_{f}} t_{f} p_{f}-q_{f}^{2},
\end{aligned}
$$

where $t_{n}=1-\frac{p_{n}-p_{f}}{q_{n}-q_{f}}$ and $t_{f}=\frac{p_{n}-p_{f}}{q_{n}-q_{f}}-\frac{p_{f}}{q_{f}}$. Note that the nonprofit maximand, $q_{n} t_{n}+q_{f} t_{f}$, simplifies to $q_{n}-p_{n}$ since $q_{n} t_{n}+q_{f} t_{f}=q_{n}\left(1-\frac{p_{n}-p_{f}}{q_{n}-q_{f}}\right)+q_{f}\left(\frac{p_{n}-p_{f}}{q_{n}-q_{f}}-\frac{p_{f}}{q_{f}}\right)=q_{n}-p_{n}$. 
Given equilibrium qualities they simultaneously choose prices in the second stage

$$
\begin{array}{ll}
\mathrm{NP}: & \max _{p_{n}} q_{n}-p_{n} \text { s.t. } t_{n} p_{n}=q_{n}^{2} \\
\mathrm{FP}: & \max _{p_{f}} t_{f} p_{f}-q_{f}^{2} .
\end{array}
$$

The nonprofit again wants to decrease its quality (compared to the quality maximization case). At the same time, it is in line with its objective if the for-profit increases its quality and gains a larger market share. The equilibrium is summarized in Table $2 .^{8}$

\begin{tabular}{|l|c|c|c|c|c|c|c|c|}
\hline NP objective & $q_{n}$ & $q_{f}$ & $p_{n}$ & $p_{f}$ & $t_{n}$ & $t_{f}$ & $O_{n}$ & $\Pi_{f}$ \\
\hline$q_{n}$ & 0.2323 & 0.0308 & 0.1079 & 0.0071 & 0.5000 & 0.2677 & 0.2323 & 0.0010 \\
$q_{n} t_{n}$ & 0.2147 & 0.0168 & 0.0697 & 0.0027 & 0.6617 & 0.1761 & 0.1421 & 0.0002 \\
$q_{n} t_{n}+q_{f} t_{f}$ & 0.2159 & 0.0174 & 0.0709 & 0.0029 & 0.6569 & 0.1788 & 0.1449 & 0.0002 \\
\hline
\end{tabular}

Table 2: Mixed duopoly under various objectives of the nonprofit

The second column from the right reports $O_{n}$, the value of the nonprofit objective function in equilibrium. The nonprofit attains the highest value under quality maximization. In this case, the market share served by the nonprofit is only 0.5 and the total market share by the two firms is 0.7677 . Intuitively in the first case, the nonprofit maximizes only quality and cares about the number of consumers only to the point that it can cover fixed production costs. In the second case, the nonprofit aims to serve a market share as large as possible with as a high quality as possible. Some of consumers that were served by the for-profit previously (those with a higher taste for quality), can now be served by the nonprofit and consume a significantly higher quality.

In the third case, the nonprofit again wants to serve a maximal possible market share with a maximal feasible quality, and at the same time, the nonprofit wants the for-profit to serve maximal possible market share with maximal possible quality. The nonprofit is willing to let its consumers with the lowest willingness to pay go under the second case

\footnotetext{
${ }^{8}$ Computational details for both stages can be found in Appendix 7.2 on page ....

To compare, in the for-profit duopoly qualities offered are 0.1242 and 0.0364 at prices 0.0474 and 0.0069 respectively. Corresponding market shares are 0.5395 and 0.2698 , and profits are 0.0101 and 0.0005 .
} 
since it can thus increase quality knowing that these consumers are profitable for and will be served by the for-profit. The for-profit is then also able to increase its quality.

\subsection{Welfare}

For the welfare analysis, let us assume that there are three types of nonprofit entrepreneurs that might enter the market: the pure quality maximizer, the quality and market share maximizer, and the maximizer of her own and her rival's quality and market share. Equilibrium outcomes of these three mixed duopoly scenarios were compared in the previous section with respect to qualities, prices, and market shares. In this subsection, the equilibrium outcomes are compared with respect to total market share served and welfare. The following table summarizes total market share covered, the profit of the for-profit, and consumer and total surplus across three alternative settings discussed above.

\begin{tabular}{|l|c|c|c|c|}
\hline NP objective & $t_{n}+t_{f}$ & $\Pi_{f}$ & CS & Total surplus \\
\hline$q_{n}$ & 0.7677 & 0.0010 & 0.0342 & 0.0352 \\
$q_{n} t_{n}$ & 0.8378 & 0.0002 & 0.0492 & 0.0494 \\
$q_{n} t_{n}+q_{f} t_{f}$ & 0.8357 & 0.0002 & 0.0489 & 0.0491 \\
\hline
\end{tabular}

Table 3: Welfare under various objectives of the nonprofit

Considering the total market share, the smallest is attained under the pure quality maximization by the nonprofit, 0.7677 . There are only small differences between the second and third alternative. In a case when the nonprofit cares about its own (and its competitor's) market share, the total market share served increases to $0.8378(0.8357)$. The for-profit earns the same profit in the second and third case, and this profit is significantly smaller than under the first alternative. Consumers are better off when the nonprofit objective also includes market share. The highest consumer surplus is attained under quality-market share maximization pursued by the nonprofit. This is driven by the surplus of consumers purchasing the nonprofit product. One half of the market consumes relatively a high quality of 0.1421 .

The total surplus is the sum of for-profit's profit and consumer surplus, and it is the 
highest in the case of quality-market share maximization by the nonprofit. Interestingly, the consumer surplus is maximized when the nonprofit cares only about its own quality and market share and not under the third alternative when the nonprofit cares also about the for-profit outcome (although the difference between the two alternatives is tiny). This result seems to stem from the fact that under the third alternative, the nonprofit takes the for-profit as a partner that helps to achieve its goal of serving as many consumers with as high a quality as possible. Nonprofit's interest also in for-profit quality means that the nonprofit sacrifices some of its consumers. These consumers will now consume smaller quality produced by the for-profit, but all consumers of the for-profit benefit because the for-profit quality increases. At the same time, the nonprofit, by letting go its consumers with the lowest willingness to pay, can increase its quality and price what transforms into a smaller consumer surplus.

\section{Alternative Cost Configurations}

Industries where nonprofits and for-profits coexist are likely to differ in the cost structure. For example, in some industries such as hospitals and education fixed costs are high while in other industries such as old-folk and nursing homes fixed costs are low relative to variable costs. The purpose of this section is to explore the effect of various cost configurations on equilibrium outcome, namely on product differentiation, market shares of the two firms, and profit opportunities of the for-profit. The setup of the problem remains the same as in Section 2 but cost specifications differ. In comparing equilibria, I start with a generalized version of quadratic fixed costs of producing quality, $c(q)=a q^{2}$ for $a \in R^{+}$, and then look at a cost function that increases slowly for low qualities and increase quickly for higher qualities, i.e. a shifted cubic function $c(q)=(q-b)^{3}+b^{3}$ with $b \in\langle 0,1 / 4\rangle$. Finally, I analyze a linear combination of variable and fixed production costs, $c(q)=b t q+(1-b) q^{2}$ with $b \in(0,1)$ and $t$ representing market share served by the firm. 


\begin{tabular}{|c|c|c|c|c|c|c|c|c|}
\hline$a$ & $q_{n}$ & $q_{f}$ & $p_{n}$ & $p_{f}$ & $t_{n}$ & $t_{f}$ & $\Pi_{n}$ & $\Pi_{f}$ \\
\hline $1 / 2$ & 0.4834 & 0.0311 & 0.2336 & 0.0075 & 0.5000 & 0.2583 & 0 & 0.0015 \\
1 & 0.2323 & 0.0308 & 0.1079 & 0.0071 & 0.5000 & 0.2677 & 0 & 0.0010 \\
2 & 0.1053 & 0.0287 & 0.0443 & 0.0060 & 0.5000 & 0.2894 & 0 & 0.0001 \\
\hline
\end{tabular}

Table 4: Numerical solutions to the mixed competition with the scaled quadratic cost function

\section{1 $c(q)=a q^{2}$}

First, I look at a small variation (in the steepness) of the fixed quadratic cost function. Intuitively, when fixed costs increase more slowly $(a<1)$ than in the benchmark case $(a=1)$, the nonprofit can enhance its quality and possibly widen the gap between its own quality and the quality of its competitor. The for-profit can then increase its profit. High levels of parameter $a$, in contrast, diminish the difference between the two products and decrease the profit of the for-profit. The first-order conditions to the problem can be found in the Appendix 8.1. Table 4 contains numerical solutions to the problem with $a=1 / 2,1$, and 2 .

These numbers show that quality differences between the two products are indeed decreasing with $a$. The difference goes from $0.4523(a=1 / 2)$ to $0.0766(a=2)$. The competition is, thus, tougher for quickly increasing cost functions. That means that the for-profit has to offer a more competitive product (with better a price-quality ratio) and its profit declines. The market share served by the nonprofit is always $1 / 2$. The market share of the for-profit is more than half of the nonprofit's share $\left(t_{f}>t_{n} / 2\right)$. It is increasing in $a$ because the product with a better price-quality ratio is purchased also by consumers with a lower taste for quality. Altogether, the total market share served is higher for higher levels of $a$.

\section{2 $c(q)=(q-b)^{3}+b^{3}$}

The cubic cost function should allow the nonprofit to increase quality similar to the quadratic costs discussed above with $a<1$. 


\begin{tabular}{|c|c|c|c|c|c|c|c|c|}
\hline$b$ & $q_{n}$ & $q_{f}$ & $p_{n}$ & $p_{f}$ & $t_{n}$ & $t_{f}$ & $\Pi_{n}$ & $\Pi_{f}$ \\
\hline 0 & 0.4535 & 0.1365 & 0.1866 & 0.0281 & 0.5000 & 0.2943 & 0 & 0.0057 \\
0.05 & 0.5159 & 0.1824 & 0.2026 & 0.0358 & 0.5000 & 0.3037 & 0 & 0.0084 \\
0.15 & 0.6299 & 0.2731 & 0.2278 & 0.0494 & 0.5000 & 0.3192 & 0 & 0.0105 \\
0.25 & 0.7209 & 0.3610 & 0.2401 & 0.0601 & 0.5000 & 0.3335 & 0 & 0.0031 \\
\hline
\end{tabular}

Table 5: Numerical solutions to mixed competition with cubic cost function

Costs increasing slowly for low quality indeed allow the nonprofit to significantly enhance its quality. Consumers' willingness to pay increases, and the nonprofit can increase the quality even further. The for-profit quality is also significantly higher when compared to the case of quadratic costs. The nonprofit again serves half of the market while the for-profit now serves about one-third of the market (compared to one-quarter). The difference in qualities is increasing with $b$, and profits earned by the for-profit also decline except in the last line when $b=0.25$. Here the flat part of the cost function corresponds to relatively high quality meaning high production costs. ${ }^{9}$

\section{3 $c(q)=b t q+(1-b) q^{2}$}

The previous analysis was focused on fixed costs of producing quality. Firms had to attract a sufficient market share to cover fixed production costs of a given quality. The analysis was motivated by art-performing organizations, for which the variable cost component is negligible relatively to the fixed cost component. In industries such as health care, however, the variable component comprises a significant fraction of total costs. Here, however, the relative size of the two components also vary. For instance, in hospitals the fixed cost component will be higher than in nursing homes where the total costs mainly comprise of variable costs of labor and the fixed costs are negligible.

To analyze the effect of variable production costs, I assume that variable costs of $t q$ are added to the quadratic fixed costs $q^{2}$. As before, $t$ represents market share served

\footnotetext{
${ }^{9}$ Results are similar to an extreme case when the costs are negligible up to a certain quality and then start to increase, e.g. for a shifted quadratic function $c(q)=0$ for $q \in\langle 0, d\rangle, d \in R^{+}$and $c(q)=(q-d)^{2}$ for $q \in\langle d, \infty)$. In this case, the nonprofit can again significantly increase its quality. The for-profit produces quality of $d$ at zero costs, and its profit is increased due to a higher product differentiation.
} 
by the firm, thus variable costs increase with quantity. Variable costs are assumed to increase with quality as well (depend positively on $q$ ) since treating additional patient in a high quality hospital is more costly than treating one more patient in a low quality hospital. ${ }^{10}$ Table 6 summarizes equilibria for three levels of $b$.

\begin{tabular}{|c|c|c|c|c|c|c|c|c|}
\hline$b$ & $q_{n}$ & $q_{f}$ & $p_{n}$ & $p_{f}$ & $t_{n}$ & $t_{f}$ & $\Pi_{n}$ & $\Pi_{f}$ \\
\hline 0 & 0.2323 & 0.0308 & 0.1079 & 0.0071 & 0.5000 & 0.2677 & 0 & 0.0010 \\
0.1 & 0.2122 & 0.0229 & 0.1113 & 0.0071 & 0.4500 & 0.2378 & 0 & 0.0007 \\
0.5 & 0.1193 & 0.0104 & 0.0881 & 0.0064 & 0.2500 & 0.1307 & 0 & 0.0001 \\
0.9 & 0.0246 & 0.0009 & 0.0233 & 0.0008 & 0.0500 & 0.0254 & 0 & 0.0000 \\
\hline
\end{tabular}

Table 6: Numerical solutions to mixed competition with fixed and variable costs

Due to the variable component of costs, the price, which each consumers has to pay, increases faster relative to the increase in quality. Since consumers are not willing to pay for a very high quality, the nonprofit has to move downward with its quality and price. And the prices are lower the higher the weight, $b$, on the variable component of the cost function.

Intuitively, market shares served are significantly lower than in the case of production costs without variable the component $(b=0)$. Both producers tend to serve only a small group of consumers with the highest willingness to pay. The nonprofit serves only $5 \%$ of the market when $b=0.9$. In this case, the total market share served is only $7.5 \%$ compared to $77 \%$ served when $b=0$ (no variable costs). Profits earned by the for-profit decline as well.

The composition of total costs thus affects the market shares served by firms. With fixed costs, it is important to attract large market share over which the costs can be distributed. With the variable costs, however, smaller market shares are preferred because each consumer has to bear the whole production costs of product/service, and firms prefer more similar consumers, i.e. consumers that do not differ in their willingness to pay too much. The sharp decline in total market share served described above is driven by

\footnotetext{
${ }^{10}$ Intuitively, treating more patients in a high quality hospital requires hiring additional high-quality physicians and nurses. This is certainly more costly than hiring physicians and nurses of lower quality.
} 
relatively high variable costs that equal the product quality. Even with smaller variable costs, we would, however, expect the tendency to serve smaller number of customers in industries with high variable costs relative to fixed costs of production. Thus, while museums or theaters attract thousands of visitors, in the nursing homes industry, there is a number of small providers treating tens of patients each.

\section{Conclusion}

In this paper, I studied the competition between one nonprofit and one for-profit firm under various objectives of the nonprofit. The nonprofit successfully competes with its for-profit counterpart under all objectives considered here. This result seems robust in a broad range of cost configurations. Moreover, in all cases, the nonprofit acts as a natural leader as in Brhlíková (2004).

In the first part of the paper, I analyzed mixed competition under various nonprofit objectives. The differences in nonprofit objectives clearly affect the quality-price bundles that are offered by competing firms. Market shares also vary. The nonprofit, for instance, serves half of the market under quality maximization while it serves about two-thirds of the market under the two other objectives: the maximization of its quality and market share and the maximization of quality and market share of both firms. The market share of the for-profit in contrast decreases in the two latter cases. Not surprisingly, profits earned by the for-profit also decline due to a diminished product differentiation. Varying market shares, qualities, and prices have an effect on consumer surplus and welfare. From the three alternatives considered in this paper, the maximum welfare is attained when the nonprofit maximizes its quality and market share.

In the second part of the paper, I analyzed mixed competition under various cost specifications focusing on the quality maximization pursued by the nonprofit. The steepness of cost functions significantly affects equilibrium qualities and market shares of the two competing firms. When variable costs are added to the fixed production costs, the 
quality decreases since each consumer has to bear production costs of a product/service. In a case when the variable component of costs overweigh the fixed component, firms serve only a small fraction of the market.

The present paper extends the analysis found in Brhlíková (2004) which is based on the assumption of quality maximization by the nonprofit and fixed quadratic production costs. Equilibrium outcomes in industries where nonprofits and for-profits coexist are affected by nonprofit objectives as well as the structure of production costs. Across all nonprofit objectives investigated here, product differentiation is large suggesting that competition is less tough than it would be if the nonprofit was also interested in profit/budget maximization. Rather than by the nonprofit objective, the toughness of the competition is to a greater extent affected by the cost function, namely its steepness and the ratio between fixed and variable cost components.

In the analysis of competition provided here the number of firms is given exogenously. In future research, it would be interesting to explore the applicability of the finiteness property (Shaked and Sutton 1983) in mixed competition setting, i.e. whether there exist an upper limit on the number of firms that can survive in the market. In mixed competition setting the question seems to be more complicated than in the case of forprofit oligopolies, since nonprofit firms are more aggressive than for-profit firms due to the non-distribution constraint. It is quite probable that another nonprofit firm would push the for-profit firm out of the market. For the coexistence and competition of several nonprofit firms, the question then would be what types of nonprofit objectives and their combinations can survive in the market.

\section{References}

Brhlíková, P. (2004). Models of competition between one nonprofit and one for-profit firm. CERGE-EI Working Paper no. 240. 
Facchina, B., E. A. Showell, and J. E. Stone (1993). Privileges and exemptions enjoyed by nonprofit organizations. University of San Francisco Law Review 28, $85-121$.

Friesner, D. and R. Rosenman (2001). The property rights theory of the firm and mixed competition: A counter-example in the US health care industry. International Journal of the Economics of Business 8(3), 437-450.

Glaeser, E. L. and A. Shleifer (2001). Not-for-profit entrepreneurs. Journal of Public Economics 81, 99-115.

Hansmann, H. B. (1981). Nonprofit enterprise in the performing arts. The Bell Journal of Economics 12, 341-361.

Hansmann, H. B. (1994). Organization of production in the human services. PONPO Working Paper No. 200 and ISPS Working Paper No. 2200.

Harrison, T. D. and K. M. Lybecker (2005). The effect of the nonprofit motive on hospital competitive behavior. Contributions to Economic Analysis \& Policy 4(1), Article 3.

Liu, Y. and C. B. Weinberg (2004). Are nonprofits unfair competitors for business: An analytical approach. Journal of Public Policy \& Marketing 23(1), 65-79.

Newhouse, J. P. (1970). Toward a theory of nonprofit institutions: An economic model of a hospital. American Economic Review 60(1), 64-74.

Pauly, M. and M. Redisch (1973). The not-for-profit hospital as a physicians' cooperative. The American Economic Review 63(1), 87-99.

Rose-Ackerman, S. (1996). Altruism, nonprofits, and economic theory. Journal of Economic Literature 34, 701-728.

Shaked, A. and J. Sutton (1983). Natural oligopolies. Econometrica 51(5), 14691483. 
Steinberg, R. (1986). The revealed objective functions of nonprofit firms. Rand Journal of Economics 17(4), 508-526. 


\section{Appendix}

\section{Alternative Objective Functions}

\subsection{The Nonprofit Maximizes $q_{n} t_{n}$}

In the second stage, the two firms simultaneously choose prices. First-order conditions follow

$$
\begin{aligned}
& 0=p_{n}\left(1-\frac{p_{n}-p_{f}}{q_{n}-q_{f}}\right)-q_{n}^{2} \\
& 0=-2 \frac{p_{f}}{q_{f}}+\frac{p_{n}-2 p_{f}}{q_{n}-q_{f}} .
\end{aligned}
$$

This system gives optimal prices

$$
\begin{aligned}
& p_{n}=\frac{q_{n}\left(q_{n}-q_{f}-\sqrt{\left(q_{n}-q_{f}\right) A}\right)}{2 q_{n}-q_{f}}, \\
& p_{f}=\frac{q_{f}\left(q_{n}-q_{f}-\sqrt{\left(q_{n}-q_{f}\right) A}\right)}{2\left(2 q_{n}-q_{f}\right)},
\end{aligned}
$$

where $A=q_{f}-q_{n}-2 q_{n}\left(2 q_{n}-q_{f}\right) .{ }^{11}$ Using the optimal prices, the objectives in the first stage can be rewritten as

$$
\begin{aligned}
& \text { NP }: \quad \max \frac{q_{n}\left(q_{n}-q_{f}-\sqrt{\left(q_{n}-q_{f}\right) A}\right)}{2\left(q_{n}-q_{f}\right)} \\
& \text { FP }: \quad \max \frac{q_{n} q_{f}\left(q_{n}-q_{f}-q_{n}\left(2 q_{n}-q_{f}\right)-\sqrt{\left(q_{n}-q_{f}\right) A}\right)}{2\left(2 q_{n}-q_{f}\right)^{2}}-q_{f}^{2}
\end{aligned}
$$

In the first stage, firms simultaneously choose qualities. First order conditions follow

\footnotetext{
${ }^{11}$ Note that there is one additional solution to the system of FOCs above with $p_{n}=$ $\frac{q_{n}\left(q_{n}-q_{f}+\sqrt{\left(q_{n}-q_{f}\right) A}\right)}{2 q_{n}-q_{f}}$ and $p_{f}=\frac{q_{f}\left(q_{n}-q_{f}+\sqrt{\left(q_{n}-q_{f}\right) A}\right)}{2\left(2 q_{n}-q_{f}\right)}$. This solution, however, does not lead to an equilibrium in the first stage.
} 


$$
\begin{aligned}
0 & =\frac{-6 q_{n}^{3}+10 q_{n}^{2} q_{f}+q_{n}^{2}-3 q_{n} q_{f}^{2}-2 q_{n} q_{f}+q_{f}^{2}+\left(q_{n}-q_{f}\right) \sqrt{\left(q_{n}-q_{f}\right) A}}{2\left(q_{n}-q_{f}\right) \sqrt{\left(q_{n}-q_{f}\right) A}} \\
0 & =\frac{q_{f}\left(-7 q_{n}^{2}-q_{n}+16 q_{n} q_{f}-6 q_{f}^{2}+\frac{q_{n}\left(A-q_{n}^{2}\right)}{\sqrt{\left(q_{n}-q_{f}\right)}}\right)}{2\left(2 q_{n}-q_{f}\right)^{2}} \\
& +\frac{\left(2 q_{n}+q_{f}\right)\left(2 q_{n}^{3}+7 q_{n}^{2} q_{f}-q_{n}^{2}-8 q_{n} q_{f}^{2}+q_{n} q_{f}+2 q_{f}^{3}+q_{n} \sqrt{\left(q_{n}-q_{f}\right) A}\right)}{2\left(2 q_{n}-q_{f}\right)^{3}}
\end{aligned}
$$

An analytical solution to this system of two equations does not seem to exist. The numerical solution given in Table 2 (section 3.2) was obtained using Mathematica v. 4.1.

\subsection{The Nonprofit Maximizes $q_{n} t_{n}+q_{f} t_{f}$}

In the second stage, the two firms choose optimal prices. FOCs are as follows:

$$
\begin{aligned}
& 0=p_{n}\left(1-\frac{p_{n}-p_{f}}{q_{n}-q_{f}}\right)-q_{n}^{2} \\
& 0=-\frac{2 p_{f}}{q_{f}}+\frac{p_{n}-2 p_{f}}{q_{n}-q_{f}}
\end{aligned}
$$

This system of FOCs has two solutions:

$$
\begin{aligned}
& p_{n}=\frac{q_{n}\left(q_{n}-q_{f} \pm q_{n} \sqrt{\left(q_{n}-q_{f}\right) A}\right)}{2 q_{n}-q_{f}}, \\
& p_{f}=\frac{q_{f}\left(q_{n}-q_{f}\right) \pm q_{f} \sqrt{\left(q_{n}-q_{f}\right) A}}{2\left(2 q_{n}-q_{f}\right)} .
\end{aligned}
$$

Maximands in the first stage then can be rewritten as 
$\mathrm{NP}: \quad \max \frac{q_{n}\left(q_{n}+\sqrt{\left(q_{n}-q_{f}\right) A}\right)}{2 q_{n}-q_{f}}$

FP $: \quad \max \frac{q_{f}\left(-2 q_{f}^{3}+8 q_{n} q_{f}^{2}-q_{n} q_{f}-7 q_{n}^{2} q_{f}+q_{n}^{2}-2 q_{n}^{3}-q_{n} \sqrt{\left(q_{n}-q_{f}\right) A}\right)}{2\left(2 q_{n}-q_{f}\right)^{2}}$.

First-order conditions are

$$
\begin{aligned}
0 & =\frac{q_{n}\left(q_{n}-q_{f}\right)\left(1+2 q_{f}-8 q_{n}\right)+A\left(q_{n}-q_{f}\left(q_{n}-q_{f}\right)\right)+2 q_{n}\left(q_{n}-q_{f}\right) \sqrt{\left(q_{n}-q_{f}\right) A}}{\left(2 q_{n}-q_{f}\right)^{2} \sqrt{\left(q_{n}-q_{f}\right) A}} \\
0 & =\frac{q_{f}\left(-6 q_{f}^{2}+16 q_{n} q_{f}-q_{n}\left(1+7 q_{n}\right)+\frac{A-2 q_{n}\left(q_{n}-q_{f}\right)}{\sqrt{\left(q_{n}-q_{f}\right) A}}\right)}{2\left(2 q_{n}-q_{f}\right)^{2}} \\
& -\frac{\left(2 q_{n}+q_{f}\right)\left(2 q_{f}^{3}-8 q_{n} q_{f}^{2}+q_{n} q_{f}+7 q_{n}^{2} q_{f}-q_{n}^{2}+2 q_{n}^{3}+q_{n} \sqrt{\left(q_{n}-q_{f}\right) A}\right)}{2\left(2 q_{n}-q_{f}\right)^{3}}
\end{aligned}
$$

Similarly to the previous section, an analytical solution to this system of two equations does not seem to exist. The numerical solution given in Table 2 (section 3.2) was obtained using Mathematica v. 4.1.

\section{Alternative Cost Configurations}

8.1 $c(q)=a q^{2}$

First-order conditions in the second stage are

$$
\begin{aligned}
& 0=p_{n}\left(1-\frac{p_{n}-p_{f}}{q_{n}-q_{f}}\right)-a q_{n}^{2} \\
& 0=-\frac{2 p_{f}}{q_{f}}+\frac{p_{n}-2 p_{f}}{q_{n}-q_{f}} .
\end{aligned}
$$


Optimal prices, as a solution to this system of first-order conditions are

$$
\begin{aligned}
& p_{n}=\frac{q_{n}\left(q_{n}-q_{f} \pm \sqrt{\left(q_{n}-q_{f}\right) B}\right)}{2 q_{n}-q_{f}}, \\
& p_{f}=\frac{q_{f}\left(q_{n}-q_{f} \pm \sqrt{\left(q_{n}-q_{f}\right) B}\right)}{2\left(2 q_{n}-q_{f}\right)}
\end{aligned}
$$

where $B=q_{f}-q_{n}-2 a q_{n}\left(2 q_{n}-q_{f}\right)$. Then the nonprofit firm chooses maximum quality for which the above price is feasible, i.e. $q_{n}=\frac{1+2 a q_{f}+\sqrt{\left(1+2 a q_{f}\right)^{2}-16 a q_{f}}}{8 a}$ implying that $\sqrt{\left(q_{n}-q_{f}\right) B}=0$. The for-profit firm then maximizes $\frac{q_{n} q_{f}\left(q_{n}-q_{f}\right)}{4\left(2 q_{n}-q_{f}\right)^{2}}-a q_{f}^{2}$.

Optimal qualities are determined as a solution to the following system of equations

$$
\begin{aligned}
& 0=\frac{1+2 a q_{f}+\sqrt{\left(1+2 a q_{f}\right)^{2}-16 a q_{f}}}{8 a} \\
& 0=-2 a q_{n}+\frac{q_{n} q_{f}\left(q_{n}-q_{f}\right)}{2\left(2 q_{n}-q_{f}\right)^{3}}+\frac{q_{n}\left(q_{n}-2 q_{f}\right)}{4\left(2 q_{n}-q_{f}\right)^{2}} .
\end{aligned}
$$

8.2 $c(q)=(q-b)^{3}+b^{3}$

First-order conditions in the second stage are

$$
\begin{aligned}
& 0=p_{n}\left(1-\frac{p_{n}-p_{f}}{q_{n}-q_{f}}\right)-\left(q_{n}-b\right)^{3}-b^{3} \\
& 0=-\frac{2 p_{f}}{q_{f}}+\frac{p_{n}-2 p_{f}}{q_{n}-q_{f}} .
\end{aligned}
$$

The system leads to the following optimal prices 


$$
\begin{aligned}
& p_{n}=\frac{q_{n}\left(q_{n}-q_{f}\right) \pm \sqrt{q_{n}\left(q_{n}-q_{f}\right) C}}{2 q_{n}-q_{f}} \\
& p_{f}=\frac{q_{f}\left(q_{n}\left(q_{n}-q_{f}\right) \pm \sqrt{q_{n}\left(q_{n}-q_{f}\right) C}\right.}{2 q_{n}\left(2 q_{n}-q_{f}\right)}
\end{aligned}
$$

where $C=q_{n}\left(q_{f}-q_{n}\right)-2\left(2 q_{n}-q_{f}\right)\left(\left(q_{n}-b\right)^{3}+b^{3}\right)$. Then the nonprofit firm chooses maximum quality for which the above price is feasible, i.e. $q_{n}=$ implying that $\sqrt{q_{n}\left(q_{n}-q_{f}\right) C}=0$. The for-profit firm then maximizes $\frac{q_{n} q_{f}\left(q_{n}-q_{f}\right)}{4\left(2 q_{n}-q_{f}\right)^{2}}-\left(q_{f}-b\right)^{3}-b^{3}$.

Optimal qualities are determined as a solution to the following system of equations

$$
\begin{aligned}
& 0=q_{n}\left(q_{n}-q_{f}\right) C \\
& 0=-3\left(q_{f}-b\right)^{2}+\frac{q_{n} q_{f}\left(q_{n}-q_{f}\right)}{2\left(2 q_{n}-q_{f}\right)^{3}}+\frac{q_{n}\left(q_{n}-2 q_{f}\right)}{4\left(2 q_{n}-q_{f}\right)^{2}} .
\end{aligned}
$$

8.3 $c(q)=b t q+(1-b) q^{2}$

First-order conditions in the second stage

$$
\begin{aligned}
& 0=\left(p_{n}-b q_{n}\right)\left(1-\frac{p_{n}-p_{f}}{q_{n}-q_{f}}\right)-(1-b) q_{n}^{2} \\
& 0=\frac{b q_{f}-2 p_{f}}{q_{f}}+\frac{p_{n}+b q_{f}-2 p_{f}}{q_{n}-q_{f}} .
\end{aligned}
$$

Optimal prices are

$$
\begin{aligned}
& p_{n}=\frac{q_{n}\left((1+b) q_{n}-q_{f} \pm \sqrt{\left(q_{n}-q_{f}\right) D}\right)}{2 q_{n}-q_{f}} \\
& p_{f}=\frac{q_{f}\left(q_{n}\left(q_{n}-q_{f}\right) \pm q_{f} \sqrt{\left(q_{n}-q_{f}\right) D}\right.}{2\left(2 q_{n}-q_{f}\right)},
\end{aligned}
$$

where $D=q_{n}\left(q_{f}-q_{n}\right)-2\left(2 q_{n}-q_{f}\right)\left(\left(q_{n}-b\right)^{3}+b^{3}\right)$. Then the nonprofit chooses maxi- 
mum quality for which the above price is feasible, i.e. $q_{n}=$ implying that $\sqrt{q_{n}\left(q_{n}-q_{f}\right) D}=$ 0 . The for-profit then maximizes $\frac{q_{n} q_{f}\left(q_{n}-q_{f}\right)}{4\left(2 q_{n}-q_{f}\right)^{2}}-\left(q_{f}-b\right)^{3}-b^{3}$.

Optimal qualities are determined as a solution to the following system of equations:

$$
\begin{aligned}
& 0=q_{n}\left(q_{n}-q_{f}\right) D \\
& 0=-3\left(q_{f}-b\right)^{2}+\frac{q_{n} q_{f}\left(q_{n}-q_{f}\right)}{2\left(2 q_{n}-q_{f}\right)^{3}}+\frac{q_{n}\left(q_{n}-2 q_{f}\right)}{4\left(2 q_{n}-q_{f}\right)^{2}} .
\end{aligned}
$$


Individual researchers, as well as the on-line and printed versions of the CERGE-EI Working Papers (including their dissemination) were supported from the following institutional grants:

- Center of Advanced Political Economy Research [Centrum pro pokročilá politicko-ekonomická studia], No. LC542, (2005-2009),

- Economic Aspects of EU and EMU Entry [Ekonomické aspekty vstupu do Evropské unie a Evropské měnové unie], No. AVOZ70850503, (2005-2010);

- Economic Impact of European Integration on the Czech Republic [Ekonomické dopady evropské integrace na ČR], No. MSM0021620846, (2005-2011);

Specific research support and/or other grants the researchers/publications benefited from are acknowledged at the beginning of the Paper.

(c) Petra Brhlíková, 2006

All rights reserved. No part of this publication may be reproduced, stored in a retrieval system or transmitted in any form or by any means, electronic, mechanical or photocopying, recording, or otherwise without the prior permission of the publisher.

Published by

Charles University in Prague, Center for Economic Research and Graduate Education (CERGE) and

Economics Institute (EI), Academy of Sciences of the Czech Republic

CERGE-El, Politických vězňů 7, 11121 Prague 1, tel.: +420 224005 153, Czech Republic.

Printed by CERGE-EI, Prague

Subscription: CERGE-EI homepage: http://www.cerge-ei.cz

Editors: Directors of CERGE and EI

Managing editors: Deputy Directors for Research of CERGE and EI

ISSN 1211-3298

ISBN 80-7343-106-8 (Univerzita Karlova. Centrum pro ekonomický výzkum a doktorské studium) ISBN 80-7344-095-4 (Akademie věd České republiky. Národohospodářský ústav) 
CERGE-EI

P.O.BOX 882

Politických vězňů 7

11121 Praha 1

Czech Republic http://www.cerge-ei.cz 